\title{
Article \\ Hybrid Power System for the Range Extension of Security Robots: Specification Development Phase
}

\author{
Woosuk Sung
}

Citation: Sung, W. Hybrid Power System for the Range Extension of Security Robots: Specification Development Phase. Appl. Sci. 2021, 11, 11577. https://doi.org/10.3390/ app112311577

Academic Editor: Manuel Armada

Received: 2 November 2021

Accepted: 29 November 2021

Published: 6 December 2021

Publisher's Note: MDPI stays neutral with regard to jurisdictional claims in published maps and institutional affiliations.

Copyright: (C) 2021 by the author. Licensee MDPI, Basel, Switzerland. This article is an open access article distributed under the terms and conditions of the Creative Commons Attribution (CC BY) license (https:/ / creativecommons.org/licenses/by/ $4.0 /)$.
School of Mechanical System and Automotive Engineering, Chosun University, Gwangju 61452, Korea; wsung@chosun.ac.kr

\begin{abstract}
This paper describes our best practices related to hybrid power system (HPS) development, with a focus on the specification development phase. The HPS specifications are based on the main development goals of our security robot, which place top priority on $24 \mathrm{~h}$ continuous operation on a single charge. Similar to human guards, security robots are expected to operate $24 \mathrm{~h}$ per day, seven days per week, but existing battery-powered robots cannot meet these goals. For long-duration missions, their operating times are too short, and their charging times are too long. As an effective alternative, hydrogen fuel cells are combined with batteries to hybridize the power systems of security robots. In this study, several HPS structures were comprehensively compared by selecting a one-stage series structure. Component specifications were determined based on the selected structure to achieve the main development goals of our security robot. To verify whether the determined specifications are valid, a HPS simulator was developed. The key operating conditions for the HPS were simulated, including overloading, terminal short-circuiting, and drive cycling. Under critical conditions, the behavior of the entire system and its components was confirmed. The developed specifications will eventually be carried over to the prototyping phase.
\end{abstract}

Keywords: hybrid power system; security robot; specification development

\section{Introduction}

Robotics technology has become popular in many fields, ranging from military to industry applications, and particularly within the physical security field. Security robots are expected to be a cost-effective method for protecting people and their property by deterring crime. State-of-the-art security robots are much more capable than previous ones. However, it is noteworthy that they are still lacking as a total replacement for human guards, who are able to respond intelligently and spontaneously to anomalies. Therefore, in current scenarios, security robots help human guards in tasks that they can perform better. For example, security robots can collect and process far more data. They can also make more regular and extended facility rounds than human guards. These rich capabilities are enabled by recent advances in hardware devices and software applications. Software applications primarily require computer vision and artificial intelligence solutions. Hardware devices involve parallel embedded computing, wireless networks, and smart sensors. Additionally, energy-dense power sources are essential for these systems to operate for a long time.

As shown in Figure 1 and Table 1, there are several security robot models that are currently available or will be available soon [1-11]. However, their detailed specifications are not yet open to the public. A majority of manufacturers only make public the overall size, appearance, and rough capabilities of their security robots. Only SMP discloses the full specifications of its S5.2 model, including the operating time and distance, in which we are particularly interested. It is noteworthy that most current models are limited in terms of these capabilities. In response to future market demands, development must be geared toward versatile capabilities for expanding the availability of robots in the physical security field. Knight-scope are currently developing a new model called the K7 in addition 

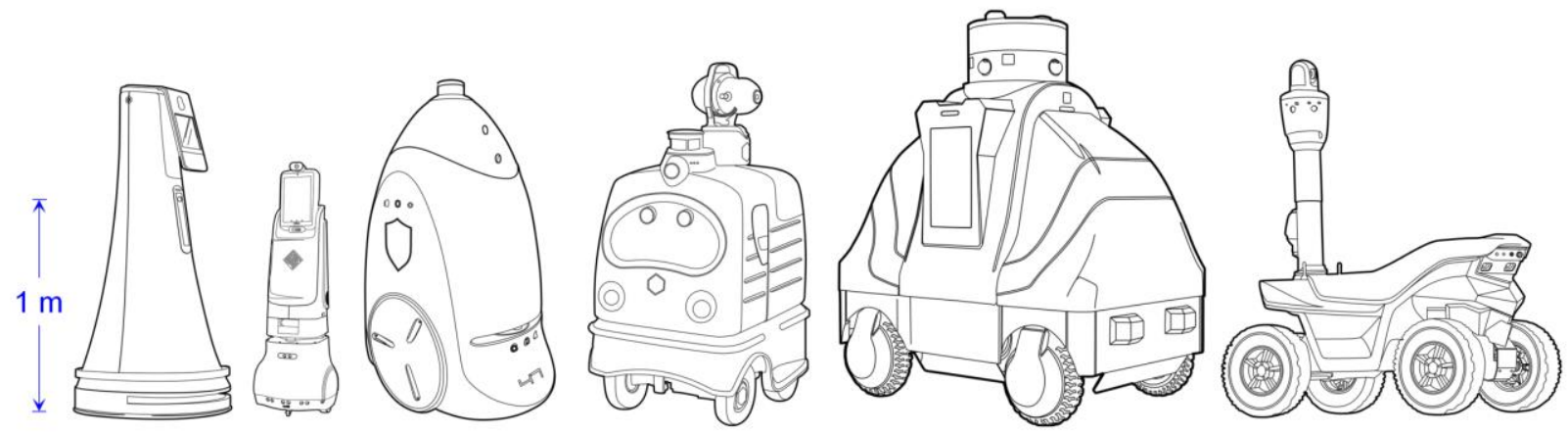

Figure 1. Size and appearance of current security robot models. COBALT, O-R2, K5, PATORO, ROAMEO, and S5.2 (from left to right).

Table 1. Comparison of current security robot models.

\begin{tabular}{|c|c|c|c|c|c|c|c|}
\hline \multicolumn{2}{|c|}{ Manufacturer } & $\begin{array}{c}\text { Cobalt } \\
\text { Robotics }\end{array}$ & OTSAW & $\begin{array}{l}\text { KNIGHT } \\
\text {-SCOPE }\end{array}$ & ZMP & RAD & SMP \\
\hline \multicolumn{2}{|c|}{ Model } & COBALT & O-R2 & K5 & PATORO & ROAMEO & S5.2 \\
\hline \multirow{3}{*}{$\begin{array}{l}\text { Dimension } \\
\text { (m) }\end{array}$} & Length & 0.533 & 0.38 & 0.914 & 0.8 & 1.8 & 1.42 \\
\hline & Width & 0.533 & 0.4 & 0.851 & 0.654 & 1.2 & 0.78 \\
\hline & Height & 1.549 & 1.15 & 1.588 & 1.089 & 1.9 & 1.32 \\
\hline \multicolumn{2}{|c|}{ Weight (kg) } & 68 & 15 & 181 & 99 & 440 & 110 \\
\hline \multicolumn{2}{|c|}{ Terrain capacity } & Indoor & Indoor & In/Outdoor & Outdoor & Outdoor & Outdoor \\
\hline \multirow{2}{*}{$\begin{array}{l}\text { Speed } \\
(\mathrm{km} / \mathrm{h})\end{array}$} & Avg. & 3.2 & & & & 9 & 4 \\
\hline & Max. & 9.7 & & 4.8 & 6 & 12.1 & 6 \\
\hline \multirow{5}{*}{$\begin{array}{l}\text { Power } \\
\text { system }\end{array}$} & Type & & LIB & & & LIB & LIB \\
\hline & Size & & $20(\mathrm{Ah})$ & & & $3.1(\mathrm{kWh})$ & $\begin{array}{c}200(\mathrm{Ah}) \\
5.12(\mathrm{kWh})\end{array}$ \\
\hline & $\begin{array}{l}\text { Charging } \\
\text { time }(\mathrm{h})\end{array}$ & & 9 & & & 9.6 & $\begin{array}{l}4 \text { (fast) } \\
6 \text { (normal) }\end{array}$ \\
\hline & $\begin{array}{l}\text { Operating } \\
\text { time }(\mathrm{h})\end{array}$ & & 10 & & & $\begin{array}{c}28.7 \\
\text { (stand-by) } \\
10.6 \text { (patrol) }\end{array}$ & $\begin{array}{l}\text { 12 16 } \\
\text { (patrol) }\end{array}$ \\
\hline & Range $(\mathrm{km})$ & & & & & & 24 \\
\hline \multicolumn{2}{|c|}{ References } & [1-3] & [4] & {$[5-7]$} & [8] & [9] & {$[10,11]$} \\
\hline
\end{tabular}

Security robots are expected to operate $24 \mathrm{~h}$ per day and 7 days per week, but batterypowered robots could not fulfill this requirement due to their not-short charging time. For refueling, they must leave off their work at least once a day or twice, meaning multiple, at least two, units have to work in shifts. Deploying a greater number of units leads to higher costs, which is contrary to public expectations that security robots are cost-effective 
methods for deterring crime. Within the physical security field, we identified a niche that is not covered by existing battery-powered robots. We propose that an alternative power source that suits the needs of security robots performing long-duration missions would be a hydrogen fuel cell. Thanks to its quick refueling in a few minutes, they need not leave off and use shift work any longer. Therefore, a single unit would be sufficient in most scenarios. By combining fuel cells with batteries, we developed a hybrid power system (HPS) for use in security robots with versatile capabilities. It is expected that in the developed HPS, the fuel cell can compensate for the insufficient energy density of the battery, and the battery can compensate for the slow transient response and relatively high power-generation cost of the fuel cell. Furthermore, if an abnormality occurs in either of these two power sources, although limited in performance, it is possible for each source to supply power to the load independently, leading to an increase in the operational reliability of the HPS.

This paper is intended to present our best practices for developing a HPS for application in security robots, with a focus on the early specification development phase. The remainder of this paper is organized as follows. In Section 2, we comprehensively compare several HPS structures and select the best configuration for our security robot. In Section 3, we determine component specifications based on the main development goals of our security robot. In Section 4, we present a simulator that allows us to verify whether the determined specifications are valid. In Section 5, we simulate a few critical operating conditions. Finally, we conclude this paper in Section 6.

\section{System Structure}

In general, the HPS can be classified into two structures: active and passive. Their main difference lies in whether one or more DC/DC converters are employed.

\subsection{Passive Structure}

A passive structure [13-16] has no converters in its power network. The fuel cell and battery are directly connected to the load. The absence of a converter yields higher efficiency, reduced cost, and a less complex structure. Despite these advantages, which are favorable for mobile robots, in reality, the passive structure is only marginally applicable. This is because with no converter in the power network, a voltage difference between the fuel cell, battery, and load is not allowed. Therefore, their voltage levels across the DC bus must be maintained at all times. However, it is difficult to acquire fuel cells that are dedicated to specific voltage requirements, particularly for prototyping. Batteries also share a similar problem, although to a lesser degree. In a passive structure, it is difficult to operate batteries within their safe voltage ranges and at desired operating points that produce the maximum efficiency or power. This would significantly dilute the benefits of the absence of a converter. Therefore, we consider the passive structure to be unsuitable for mobile robot applications.

\subsection{Active Structure}

An active structure $[13,17,18]$ contains converters in its power network. The fuel cell is coupled to the battery by a converter. Additionally, the battery may be connected to the load by a converter. Different types of DC/DC converters are placed at different locations in the power network to configure different active structures.

Ramos et al. [13] introduced four hybrid structures, but only two were considered to be active (see Figure 2). One is referred to as a semi-active (SA) structure, and the other is referred to as a fully active (FA) structure. In the SA structure, the battery is connected to the fuel cell by a converter, and the battery is directly coupled with the load. In this structure, the battery voltage is determined by the load, similar to the passive structure. In contrast, in the FA structure, the battery is connected to the load by a converter. Therefore, the battery voltage can be controlled to some extent and is not fully dependent on the load. In this paper, they numerically assessed these hybrid structures using computer simulations. Consequently, the SA structure was selected on the basis of performance 
metrics such as hydrogen consumption and component degradation. However, for an actual implementation, they concluded that it is also necessary to account for constructive metrics such as component availability in the market.

(a)

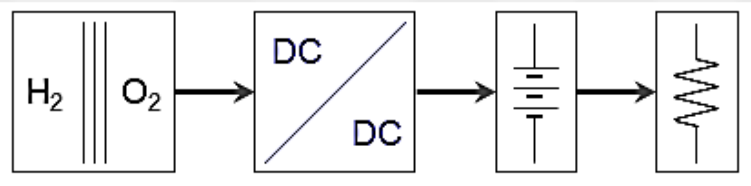

(b)

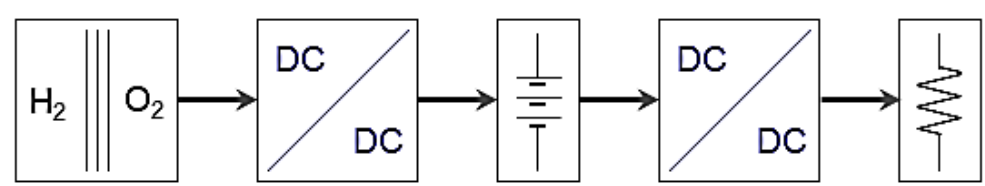

(c)

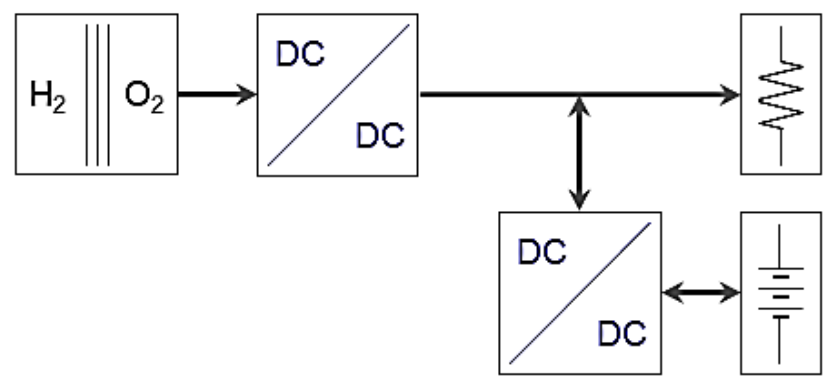

Figure 2. Comparison of active hybrid structures. (a) One-stage series (semi-active), (b) two-stage series (fully active), and (c) two-stage parallel.

Joo et al. [18] proposed three active hybrid structures, called the one-stage series, two-stage series, and two-stage parallel structure (see Figure 2). Here, two-stage indicates two converters in a power network. In terms of Ramos et al.'s work [13], the one-stage series is equivalent to the SA, and the two-stage series corresponds to the FA. The novel configuration presented in this paper is the two-stage parallel structure, where the battery is connected to the load in parallel. They theoretically assessed these three hybrid structures. As a basis for comparison, a number of performance metrics were considered, including efficiency, complexity, output voltage regulation, design flexibility, peak load capability, controllability, and responsiveness to load changes. As a result, the two-stage parallel structure was selected because it can regulate the load voltage efficiently. They claimed that efficiency and controllability are the most crucial performance metrics in the field of power conversion.

\subsection{Selected Structure}

The claims above are generally agreeable, but we prioritized complexity, which is closely linked to the weight, volume, and cost of the HPS. Since the developed HPS will be commercialized with a security robot, higher priority should be given to cost with consideration for mass production. As described above, the introduction of fuel cell technology into a HPS is a strategic choice to achieve the $24 \mathrm{~h}$ continuous operation of security robots. However, a hydrogen fuel cell is expensive to construct and operate. To minimize cost increases, the one-stage series structure was adopted, which is the least complicated configuration among the active hybrid structures proposed thus far. In addition, the one-stage series structure is of equal or greater quality than other configurations in four out of seven performance metrics, including efficiency, complexity, controllability, and responsiveness to load changes. Based on their advantages and disadvantages, details on this comparison can be found in [18]. 
In the selected structure, the converter steps the fuel cell voltage down to the DC bus voltage, allowing the fuel cell to run at a lower voltage level. According to the output voltage of the converter, a voltage difference develops between the converter and battery, which determines the power flow. Although the power flows of the fuel cell (outgoing) and load (incoming) are fixed by nature, that of the battery is variable. If the converter voltage is set higher than the battery voltage, then the battery is charged (incoming) until the voltage difference is eliminated (see Figure 3a). Otherwise, the battery is discharged (outgoing) until the voltage difference is eliminated if the load is applied to the HPS (see Figure $3 b$ ). Under load, a voltage difference is induced by the difference in dynamic characteristics between the two power sources in that the battery supplies power to the load before the fuel cell. In doing so, the power flow from/to the battery flips back and forth, such that the battery can maintain the state-of-charge (SOC), and the HPS can maintain the DC bus voltage higher than the rated voltage of the load.

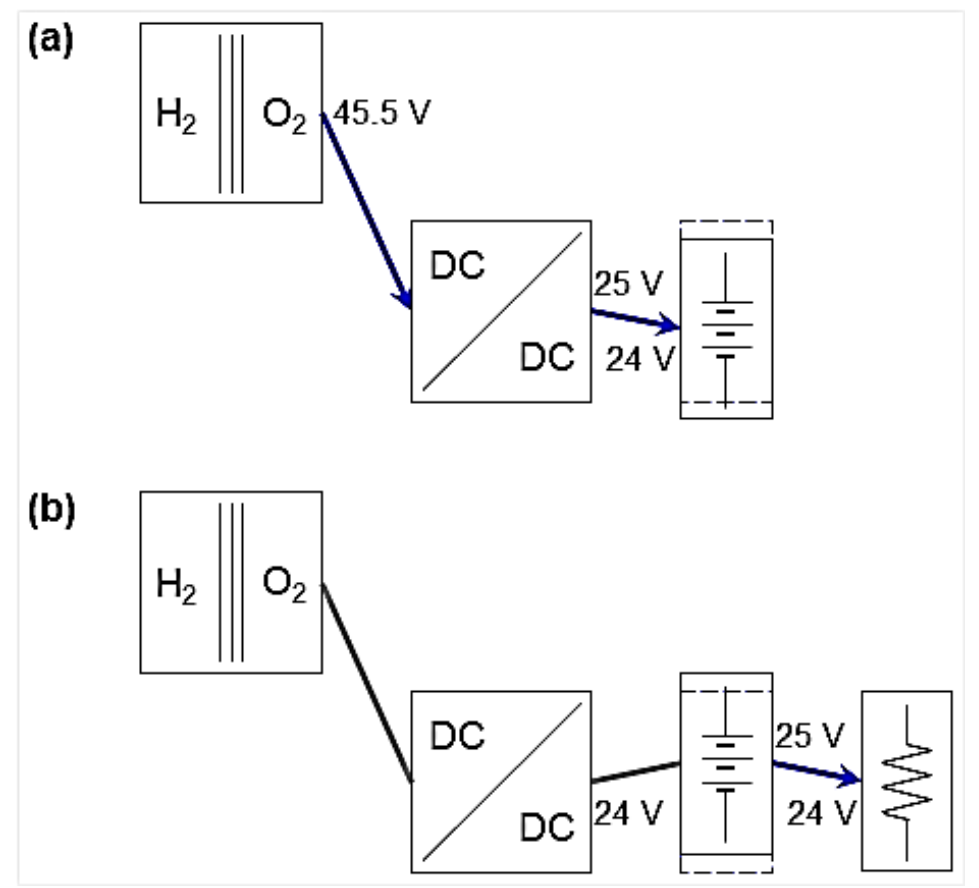

Figure 3. Variations in the power flow within the selected structure. (a) Incoming to battery and (b) outgoing from battery.

\section{Component Specifications}

To develop specifications for individual components in the HPS, the requirements for the security robot were investigated first. Table 2 lists 8 HPS-related ones out of 18 overall requirements, which can be considered as development goals. For the HPS, there are two major electrical specifications to be determined: power and energy.

\subsection{Energy Specification}

The energy specification can be set based on the main development goal of our security robot, namely $24 \mathrm{~h}$ continuous operation on a single charge. As stated previously, the operation modes of the security robot can be divided into surveillance and surveillance during patrolling. The average power required for each mode was estimated to be approximately 250 and $450 \mathrm{~W}$, respectively. The mechanical power required for patrolling is thus $200 \mathrm{~W}$, which is mostly consumed by electric motors. The electrical power required for surveillance is primarily consumed by sensors and computers in the security robot. 
Assuming that the vehicle is moving on paved, rough, and flat ground at a constant velocity, the required power, $P(200 \mathrm{~W})$, is estimated as follows:

$$
P=\frac{F \cdot v}{\eta}
$$

where $F$ is the total tractive effort $(92.75 \mathrm{~N}), v$ is the average velocity $(5 \mathrm{~km} / \mathrm{h}=1.39 \mathrm{~m} / \mathrm{s})$, and $\eta$ is the lumped efficiency (0.657). The total tractive effort, $F$, which is the force propelling the vehicle forward, is calculated as:

$$
F=F_{r r}+F_{a d}+F_{h c}+F_{l a}+F_{a a}
$$

where $F_{r r}$ is the rolling resistance force, $F_{a d}$ is the aerodynamic drag, $F_{h c}$ is the hill climbing force, $F_{l a}$ is the force required to provide linear acceleration to the vehicle, and $F_{a a}$ is the force required to provide angular acceleration to the electric motors. Under the assumptions above, only $F_{r r}$ and $F_{a d}$ are accounted for. The rolling resistance force, $F_{r r}(92.75 \mathrm{~N})$, is calculated as:

$$
F_{r r}=\mu_{r r} m g,
$$

where $\mu_{r r}$ is the coefficient of rolling resistance (0.03) and $m$ is the vehicle weight $(270 \mathrm{~kg})$. Although negligible compared to $F_{r r}$, the aerodynamic drag, $F_{a d}(0.53 \mathrm{~N})$, is evaluated as:

$$
F_{a d}=\frac{1}{2} \rho A C_{d} v^{2},
$$

where $\rho$ is the air density $\left(1.25 \mathrm{kgm}^{-3}\right), A$ is the frontal area $\left(1.1 \mathrm{~m}^{2}\right), C_{d}$ is the drag coefficient $(0.4)$, and $v$ is the average velocity $(1.39 \mathrm{~m} / \mathrm{s})$. Different power conversion efficiencies are combined into the overall efficiency, $\eta(0.657)$, which includes the electric motors with their reduction gear (0.75) and the DC/DC converter (0.9). Therefore, the mechanical power required for patrolling was estimated to be $196 \mathrm{~W}$. For simplicity, we consider a value of $200 \mathrm{~W}$. The electrical power required for surveillance was assumed to be $250 \mathrm{~W}$. If the security robot surveils for half of $24 \mathrm{~h}(250 \mathrm{~W} \times 12 \mathrm{~h}=3 \mathrm{kWh})$ and surveils while patrolling for the other half $(450 \mathrm{~W} \times 12 \mathrm{~h}=5.4 \mathrm{kWh})$, the total energy required adds up to $8.4 \mathrm{kWh}$. As sources of the parameter values used to evaluate the mechanical power required for patrolling, $\eta, \mu_{r r}$, and $\rho$ were as referred to in $[19,20], m$ and $A$ were measured, and $C_{d}$ was estimated.

Table 2. Security robot's requirements pertaining to HPS.

\begin{tabular}{cccc}
\hline Speed $(\mathrm{km} / \mathrm{h})$ & $\begin{array}{c}\text { Avg. } \\
\text { Max. }\end{array}$ & $\begin{array}{c} \\
\end{array}$ & \\
\hline Climbable angle $\left({ }^{\circ}\right)$ & 18 & \\
\hline Climbable step-obstacle height $(\mathrm{cm})$ & 20 & \\
\hline Charging time $(\mathrm{h})$ & 1 & $\begin{array}{c}\text { Compressed hydrogen } \\
\text { used as a fuel }\end{array}$ \\
\hline Operating time $(\mathrm{h})$ & 24 & \\
\hline Range $(\mathrm{km})$ & 70 & \\
\hline Operating temperature $\left({ }^{\circ} \mathrm{C}\right)$ & $-20 \sim 45$ & Based on the size of pebble \\
Terrain capacity $(\mathrm{mm})$ & 40 &
\end{tabular}

Assuming that the gravimetric energy density of the battery used in the HPS is approximately $100 \mathrm{Wh} / \mathrm{kg}$ and the required energy is supplied by batteries alone, batteries weighing over $80 \mathrm{~kg}$ would be required. Although the weight of batteries varies in direct proportion to the energy stored inside them, this is not the case for fuel cells. Fuel cells can 
supply as much energy as necessary without increasing their weight. It is the weight of the fuel, rather than that of the fuel cell, that increases. This is one of the main advantages of fuel cells over batteries. The energy density of a fuel depends on the applied hydrogen storage technology. If hydrogen is stored at 300 bar of pressure, in electrical terms, its energy density will be nearly $33.3 \mathrm{kWh} / \mathrm{kg}$ [21]. If the efficiency of the fuel cell used in the HPS is $40 \%$, then the energy density of the hydrogen will be reduced to $13.2 \mathrm{kWh} / \mathrm{kg}$. By dividing the total energy required $(8.4 \mathrm{kWh})$ by this value, the weight of hydrogen required was estimated to be approximately $0.63 \mathrm{~kg}$.

\subsection{Power Specification}

The power specification can also be set based on one of the development goals of our security robot, namely climbing a slope of $18^{\circ}$. The average power required for surveillance while patrolling at an $18^{\circ}$ inclination was estimated to be approximately $1535 \mathrm{~W}$. As the electrical power required for surveillance remains unchanged at $250 \mathrm{~W}$, the mechanical power required for patrolling is hence $1285 \mathrm{~W}$. The estimation process is the same as before, except that the hill climbing force, $F_{h c}(819 \mathrm{~N})$, is calculated as:

$$
F_{h c}=m g \sin \theta,
$$

where $m$ is the vehicle weight $(270 \mathrm{~kg})$ and $\theta$ is the slope angle $\left(18^{\circ}\right)$.

\subsection{Selected Components}

Prior to selecting the active components in the HPS, it was necessary to handle the major passive component that propels the security robot forward. Based on multiple development goals that needed to be achieved simultaneously, an electric motor of the $24 \mathrm{~V}$ brushless DC type was selected (NPC Robotics, T74, Mound, Minnesota, United States). LIB cells with a 2.5 Ah nominal discharge capacity and $3.6 \mathrm{~V}$ nominal voltage were selected (Samsung SDI, 18650-25R). To match the rated voltage of the load (24 V), seven cells were connected in series to produce a 7S configuration. It should be noted that most of the time, the fuel cell will operate at the average power (listed in the energy specification). However, occasionally, the HPS may run at a higher power level (listed in the power specification). If this higher power demand is frequent and/or long-lasting, the battery may need to bear it without any time to recharge from the fuel cell. In turn, the HPS may fail to maintain the DC bus voltage at a level higher than the rated voltage of the load. To withstand these overload conditions, the series-connected cells were reconnected in parallel, yielding a battery pack based on a 7S8P configuration. Fuel cells within a stack with a nominal power of $1 \mathrm{~kW}$ were selected (Horizon Fuel Cell Technologies, H-1000 W). The fuel cell stack is a series of 48 proton exchange membrane cells. Based on their nominal power levels, the off-the-shelf fuel cell models worth consideration include $0.5,1,2$, and up to $3 \mathrm{~kW}$ models. Although the $500 \mathrm{~W}$ model is the closest to the average power, the nominal power should be doubled to cope with overload conditions. At the output of the fuel cell, a DC/DC converter with a rated power of $960 \mathrm{~W}$ was selected (Mean Well, SD-1000L-24). It features an input voltage range of 19 to $72 \mathrm{~V}$ and an output voltage of $24 \mathrm{~V}$, which is manually adjustable from 23 to $30 \mathrm{~V}$. At the input of the fuel cell, four composite cylinders (two up and two down) were connected in parallel to store up to $0.71 \mathrm{~kg}$ of hydrogen compressed at 310 bar (Inocom, SCBA-9.0L).

Table 3 lists the specifications of the selected components. As discussed above, we developed the electrical specifications of the HPS to help us achieve the development goals of the security robot. However, the developed specifications are limited in that under sudden load changes, the instantaneous behavior of the entire system and its components is difficult to calculate and must be observed through actual tests. However, in the early specification development phase, a HPS prototype and test bench were not ready to be used. To overcome these difficulties, a HPS simulator was developed. 
Table 3. Selected component specifications.

\begin{tabular}{|c|c|c|c|}
\hline Fuel cell & $\begin{array}{c}\text { Type } \\
\text { Configuration } \\
\text { Voltage }(\mathrm{V}) \\
\text { Power }(\mathrm{W})\end{array}$ & $\begin{array}{c}\text { PEM } \\
48 S \\
45.5 \sim 28.8 \\
1000\end{array}$ & Nominal \\
\hline Fuel storage & $\begin{array}{c}\text { Type } \\
\text { Configuration } \\
\text { Mass }(\mathrm{kg})\end{array}$ & $\begin{array}{c}\text { Composite } \\
4 \mathrm{P} \\
0.71\end{array}$ & $\begin{array}{l}\text { Full-wrapped carbon fiber } \\
\text { Compress at } 310 \text { bar }\end{array}$ \\
\hline Battery & $\begin{array}{c}\text { Type } \\
\text { Configuration } \\
\text { Voltage (V) } \\
\text { Capacity (Ah) }\end{array}$ & $\begin{array}{c}\text { NMC } \\
7 S 8 P \\
29.4 \sim 17.5 \\
20\end{array}$ & Nominal \\
\hline $\begin{array}{l}\text { DC/DC } \\
\text { converter }\end{array}$ & $\begin{array}{c}\text { Type } \\
\text { Voltage (V) } \\
\text { Power (W) }\end{array}$ & $\begin{array}{l}\text { Non-isolated } \\
19 \sim 72 \text { to } 24 \\
960\end{array}$ & $\begin{array}{c}\text { Input to Output } \\
\text { Rated }\end{array}$ \\
\hline
\end{tabular}

\section{Simulator Development}

Simulink was used to verify the selected HPS structure and its component specifications. In this software, complex systems can be simulated easily by visually modeling individual components and then connecting them to each other. The HPS we attempted to model integrates multiple domains, including mechanical, chemical, and electrical components. Simscape, which is an extension to Simulink, was primarily applied to efficiently model such a multi-domain system.

\subsection{Fuel Cell Model}

The fuel cell stack block [22,23] in the Simscape library was used to model the fuel cell in the HPS. Two different versions are available for this block: a simplified model and a detailed model. The simplified model describes a fuel cell stack as a controlled voltage source in series with constant resistance (see Figure 4). In this model, the fuel cell voltage is expressed as:

$$
V_{f c}=E_{o c}-V_{a c t}-V_{r}
$$

with activation overpotential of:

$$
V_{a c t}=N A \ln \left(\frac{i_{f c}}{i_{0}}\right) \cdot \frac{1}{s T_{d} / 3+1},
$$

and ohmic and mass transport overpotential of:

$$
V_{r}=r_{o h m} \cdot i_{f c},
$$

where $E_{o c}$ is the open-circuit voltage $(\mathrm{V}), N$ is the number of cells, $A$ is the Tafel slope $(\mathrm{V}), i_{f c}$ is the fuel cell current $(\mathrm{A}), i_{0}$ is the exchange current (A), $T_{d}$ is the settling time (s) defined by three time constants, and $r_{\text {ohm }}$ is the combined ohmic and mass transport resistance (ohm).

A useful feature of this block is that we do not need to input elusive model parameter values. Instead, we simply input the current-voltage curve of the fuel cell to be used. The model parameter values are then automatically derived from the shape of the curve. This shape can be defined by the voltages at $0 \mathrm{~A}$ and $1 \mathrm{~A}$, and the nominal and maximum operating points. A typical current-voltage curve of a fuel cell consists of three regions, and these four points help break the curve apart. These three regions represents the activation, ohmic, and mass-transport losses. We attempted to input the four points of the selected fuel cell, but in its data sheet, clear distinctions were not made between the nominal, peak, and rated powers. They are all likely to be $1 \mathrm{~kW}$. Therefore, the maximum operating point 
was set to $34 \mathrm{~V}$ at $30 \mathrm{~A}$ and the nominal operating point was assumed to be $35.5 \mathrm{~V}$ at $20 \mathrm{~A}$. Table 4 lists the fuel cell model parameters.

Table 4. Fuel cell model parameters.

\begin{tabular}{|c|c|c|}
\hline \multicolumn{2}{|c|}{ Voltage at $0 \mathrm{~A}$ and $1 \mathrm{~A}(\mathrm{~V})$} & $45.5,40$ \\
\hline \multicolumn{2}{|c|}{ Nominal operating point $(\mathrm{A}, \mathrm{V})$} & $20,35.5$ \\
\hline \multicolumn{2}{|c|}{ Maximum operating point $(\mathrm{A}, \mathrm{V})$} & 30,34 \\
\hline \multicolumn{2}{|c|}{ Number of cells } & 48 \\
\hline \multicolumn{2}{|c|}{ Nominal stack efficiency (\%) } & 40 \\
\hline \multicolumn{2}{|c|}{ Operating temperature $\left({ }^{\circ} \mathrm{C}\right)$} & 25 \\
\hline \multicolumn{2}{|c|}{ Nominal air flow rate (lpm) } & 300 \\
\hline \multirow{2}{*}{$\begin{array}{l}\text { Nominal supply } \\
\text { pressure (bar) }\end{array}$} & Fuel & 0.5 \\
\hline & Air & 1 \\
\hline \multirow{3}{*}{$\begin{array}{c}\text { Nominal } \\
\text { composition }(\%)\end{array}$} & $\mathrm{H}_{2}$ & 99.999 \\
\hline & $\mathrm{O}_{2}$ & 21 \\
\hline & $\mathrm{H}_{2} \mathrm{O}$ (Air) & 1 \\
\hline \multicolumn{2}{|c|}{ Response time (s) } & 1 \\
\hline
\end{tabular}

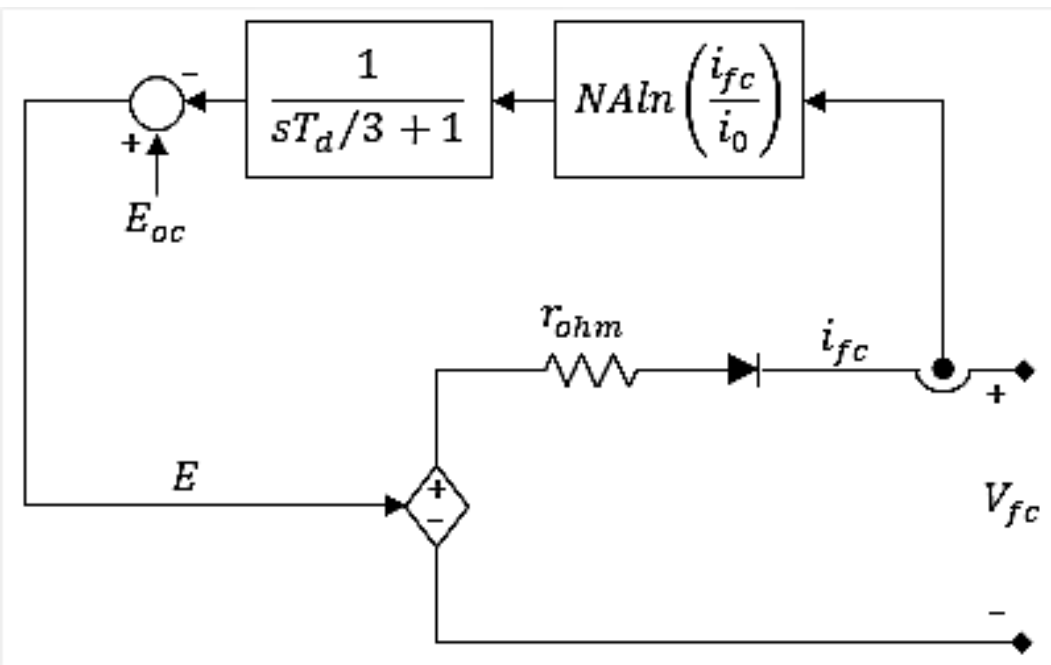

Figure 4. Circuit schematic for fuel cell model.

\subsection{Battery Model}

Similarly, the battery block [24,25] in the Simscape library was employed to model the battery in the HPS. Many different versions are implemented in this block according to the type of rechargeable battery. The LIB model represents a battery cell as a controlled voltage source in series with a constant resistance (see Figure 5). This model is based on the modified Shepherd curve-fitting model with the addition of a polarization voltage term to the battery voltage expression, such that the effects of the SOC on battery performance could be better represented. With this model, the battery voltage is expressed as:

$$
V_{b a t t}=E_{0}-K \frac{Q}{Q-i t}+A \exp (-B \cdot i t)-R_{b} \cdot I
$$

where $E_{0}$ is the open-circuit voltage $(\mathrm{V}), K$ is the polarization constant (V/Ah), $Q$ is the battery capacity (Ah), it is the actual battery charge (Ah), $A$ is the exponential zone amplitude $(\mathrm{V}), B$ is the exponential zone time constant inverse $\left(\mathrm{Ah}^{-1}\right)$, and $R_{b}$ is the battery internal resistance (ohm). 


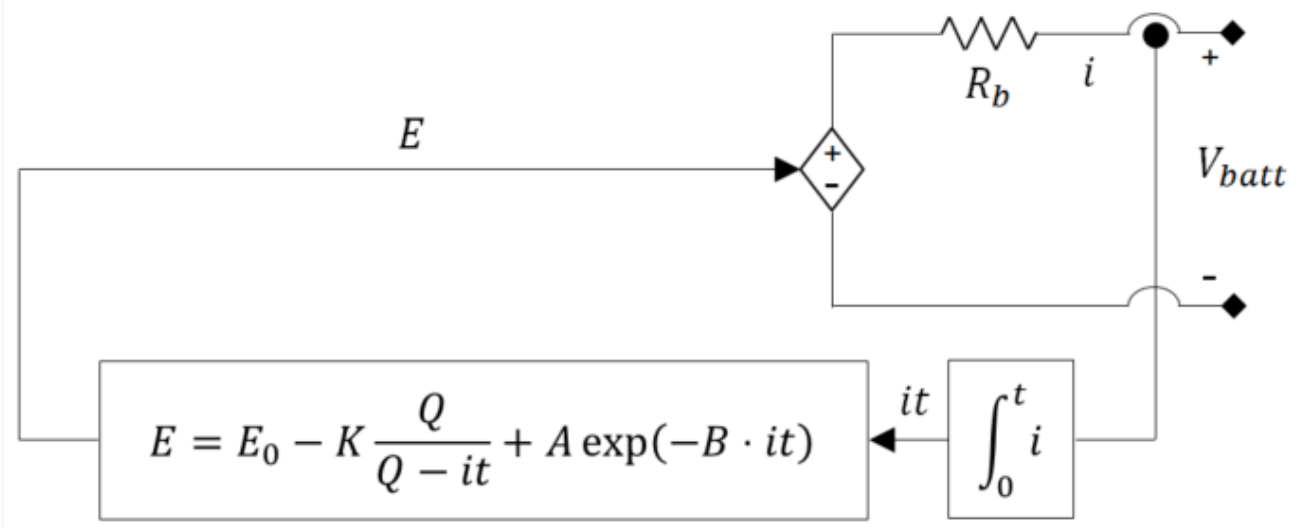

Figure 5. Circuit schematic for battery model.

Instead of inputting model parameter values, we input the capacity-voltage curve of the battery to be used. The shape of this curve is mainly defined by the nominal voltage, rated capacity, and initial SOC. Its shape can be more sophisticated with the maximum capacity, cutoff voltage, fully charged voltage, nominal discharge current, internal resistance, and capacity at the nominal voltage and exponential zone. Among them, the nominal voltage should be carefully selected with the corresponding capacity. In general, it is captured from the middle of the curve, which typically corresponds to 3.6-3.8 V. However, in this block, it is captured almost at the end of the curve, where the voltage rapidly drops to below $3.3 \mathrm{~V}$ (see Figure 6). With lithium-iron-phosphate (LFP) batteries, the nominal voltage is relatively distinctive because the shape of the curve is mostly straight with a sharp bend at the end. However, with the selected battery, the nominal voltage is unclear because the battery is based on lithium-nickel-manganese-cobalt-oxide (NMC). Unlike LFP, the shape of the curve is mostly smooth without any sharp bending. By referring to the corresponding datasheet, the nominal voltage was assumed to be $3.3 \mathrm{~V}$. With a battery pack in the 7S8P configuration, it would be $23.1 \mathrm{~V}$. The exponential zone also shares a similar problem. The end of the exponential zone is not plainly visible based on the shape of the curve. The nominal voltage was roughly determined to be $24.984 \mathrm{~V}$ at $7.5 \mathrm{Ah}$. Table 5 lists the parameters of the battery model.

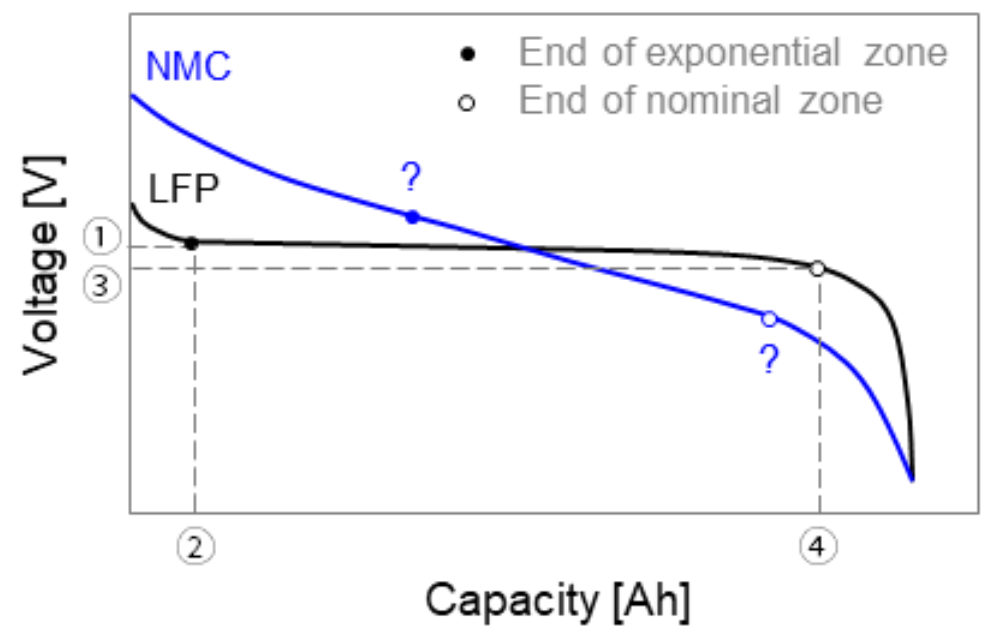

Figure 6. Comparison of NMC and LFP batteries in terms of extracting key parameters from the polarization curve. $(1,2)$ Exponential zone $(\mathrm{V}, \mathrm{Ah}),(3)$ nominal voltage $(\mathrm{V})$, and $(4)$ capacity at nominal voltage $(\mathrm{Ah})$. 
Table 5. Battery model parameters.

\begin{tabular}{ccc}
\hline Nominal voltage (V) & 23.1 & $3.3 \times 7 \mathrm{~S}$ \\
\hline Rated capacity (Ah) & 20 & $2.5 \times 8 \mathrm{P}$ \\
\hline Initial state-of-charge (\%) & 50 & \\
\hline Battery response time & 30 & $2.5 \times 7 \mathrm{~S}$ \\
\hline Max. capacity (Ah) & 20 & $4.2 \times 7 \mathrm{~S}$ \\
\hline Cut-off voltage (V) & 17.5 & $1 \mathrm{C}$ \\
\hline Fully charged voltage (V) & 29.4 & $2.1 \times 8 \mathrm{P}$ \\
\hline Nominal discharge current (A) & 20 & $3.74 \times 7 \mathrm{~S}$ \\
\hline Internal resistance (ohm) & 0.01 & $0.73 \times 8 \mathrm{P}$ \\
\hline Capacity at nominal voltage (Ah) & 16.8 & \\
\hline
\end{tabular}

\subsection{Converter Model}

In the HPS, a converter is required to regulate the DC bus voltage (low-side) while limiting the fuel cell current (high-side). In this manner, the HPS can maintain the DC bus voltage higher than the rated voltage of the load. Additionally, the fuel cell can operate at the desired operating point, despite significant variations in load demand. Based on these requirements, the buck converter block [26] in the Simscape library was modified with voltage and current regulators, and a current limiter.

The modified converter block is a non-isolated type in which a switch such as a chopper regulates the current flow and an inductor stores energy when the current flows through it (see Figure 7). The output voltage of the converter can be adjusted according to a switching frequency. Since the switching frequency typically reaches several kilohertz, the time interval required to simulate the switching behavior is infinitesimal. Therefore, the switching model is extremely time-consuming.

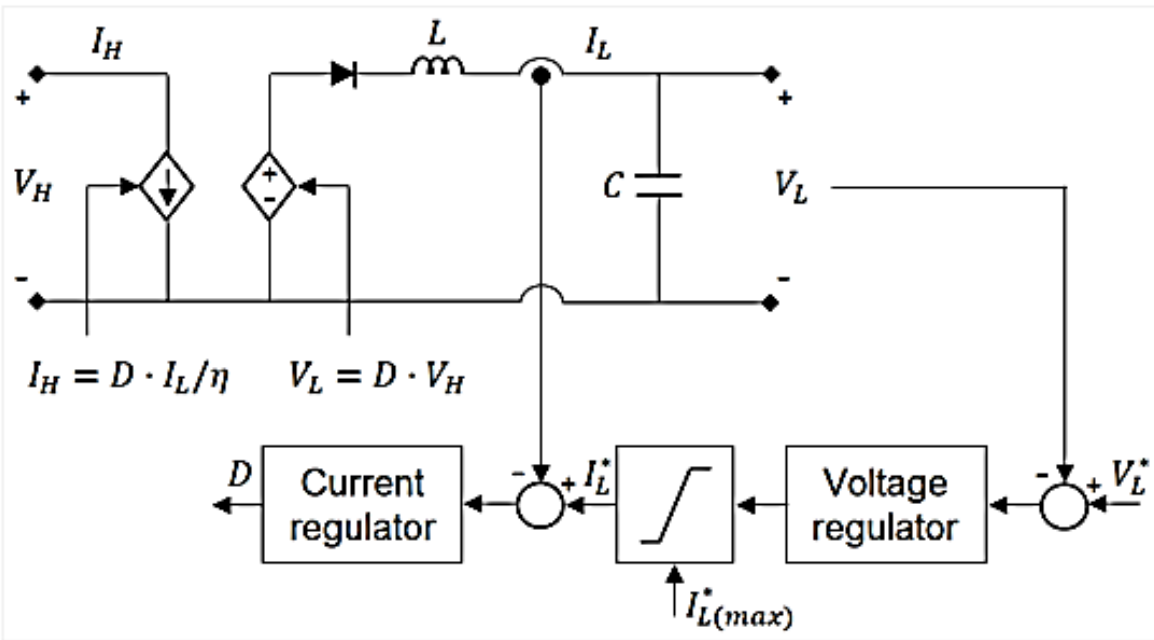

Figure 7. Circuit schematic for converter model.

In contrast, another type of model, called the average model, is computationally inexpensive. This is because pulse-width modulation generator-based switches are replaced with a simple switching function in the buck converter block, which can be directly controlled by a duty cycle (see Figure 8). To adjust the duty cycle, the current regulator is installed in series with the voltage regulator. The voltage regulator block takes the reference voltage as an input and outputs the current demand to compensate for the voltage error. 
The current demand is limited before being inputted into the following block. The current regulator block takes the limited reference current as an input and outputs the duty cycle that the switching function in the buck converter block takes as an input. Table 6 lists the parameters of the converter model.

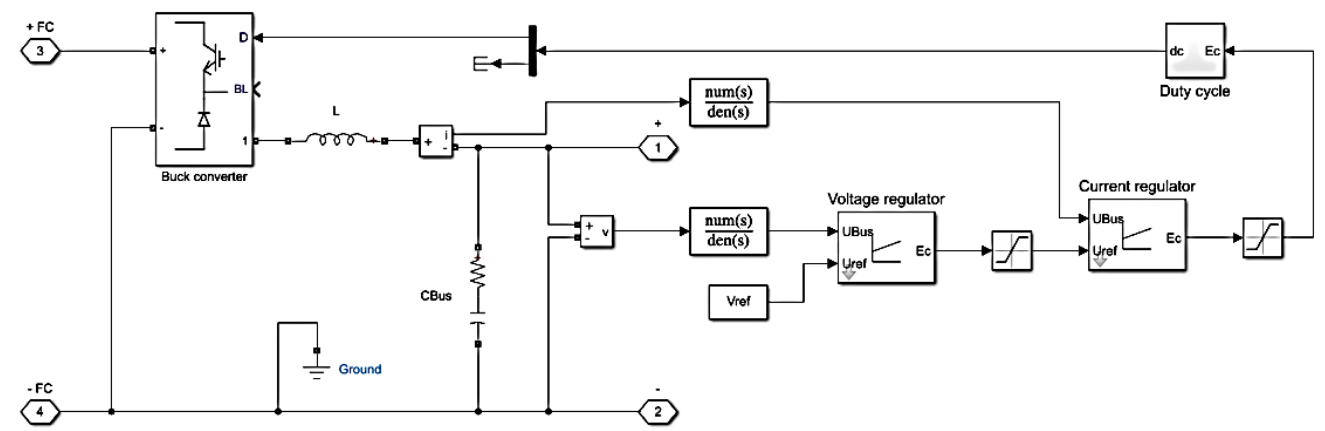

Figure 8. Circuit schematic for converter model simulation.

Table 6. Converter model parameters.

\begin{tabular}{ccc}
\hline \multicolumn{2}{c}{ Input voltage $(\mathrm{V})$} & $45.5 \sim 28.8$ \\
\hline \multicolumn{2}{c}{ Reference voltage $(\mathrm{V})$} & 25.15 \\
\hline \multicolumn{2}{c}{ Max. current $(\mathrm{A})$} & 30 \\
\hline $\begin{array}{c}\text { Voltage } \\
\text { regulator }\end{array}$ & P-gain & 3 \\
Current & I-gain & 10 \\
regulator & P-gain & 0.004 \\
\hline & Inductance $(\mu \mathrm{H})$ & 2 \\
\hline & Capacitance $(\mu \mathrm{F})$ & 500 \\
\hline \multicolumn{2}{c}{ Load resistance $(\mathrm{ohm})$} & 7500 \\
\hline
\end{tabular}

Through the converter block, the fuel cell stack block is connected to the battery block and load block (see Figure 9). The load block takes the power demand as an input and outputs the current demand that the controlled current source takes as an input. In this manner, the controlled current source simulates the load in the form of power versus time, which is called a power profile.

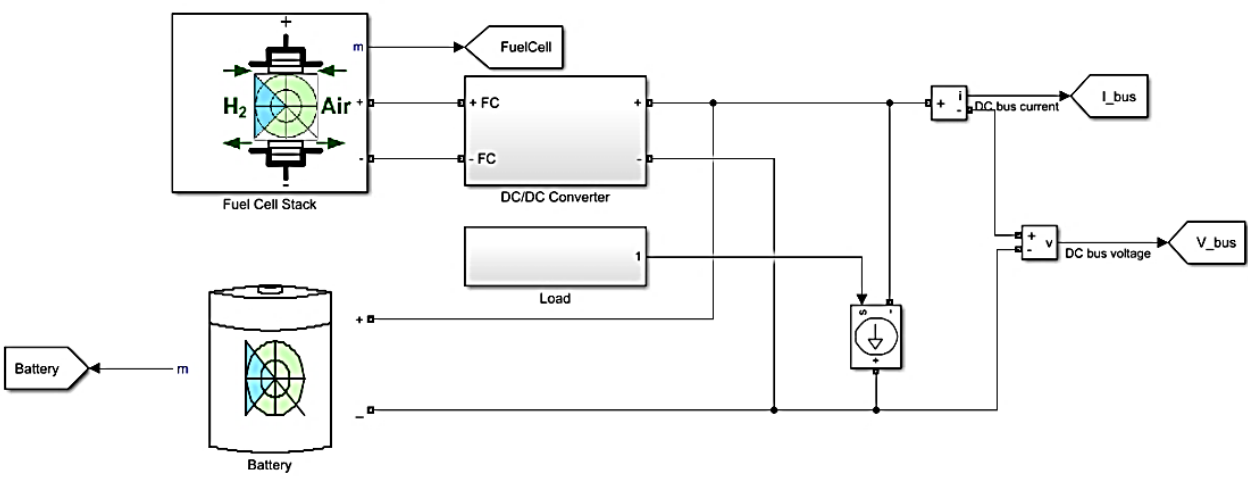

Figure 9. Circuit schematic for overall system simulation.

\section{Simulation Verification}

During the specification development phase, it is difficult to verify the selected HPS structure and its component specifications because the actual operating conditions of the security robot are unclear. This problem was approached by considering key operating conditions with overloading, terminal short-circuiting, and a drive cycle. 


\subsection{Overloading}

When ascending a slope of $18^{\circ}$, as calculated previously, the load demand (1535 W) will be higher than the power supply from the HPS. The first simulation we conducted focused on fluctuating DC bus voltages under such overload conditions, which should be maintained well above the rated voltage of the load. In this simulation, the load was increased in steps of $500 \mathrm{~W}$ up to a maximum of $3 \mathrm{~kW}$, and each load lasted for $60 \mathrm{~s}$ (see Figure 10).

(a)

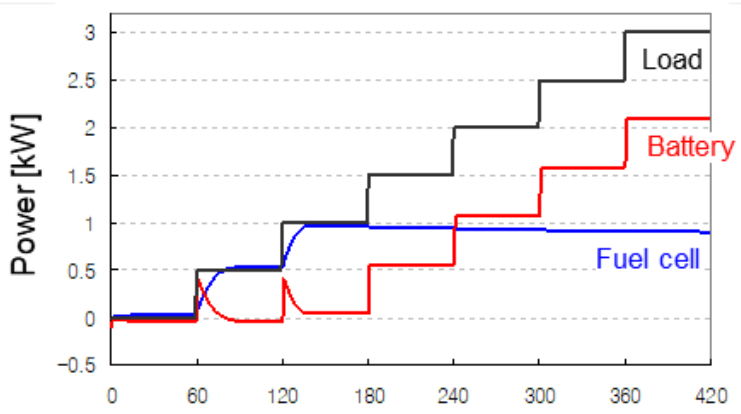

(b)

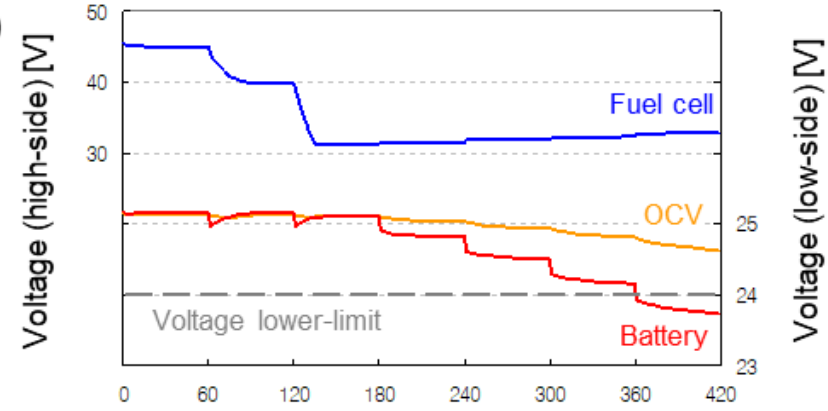

(c)

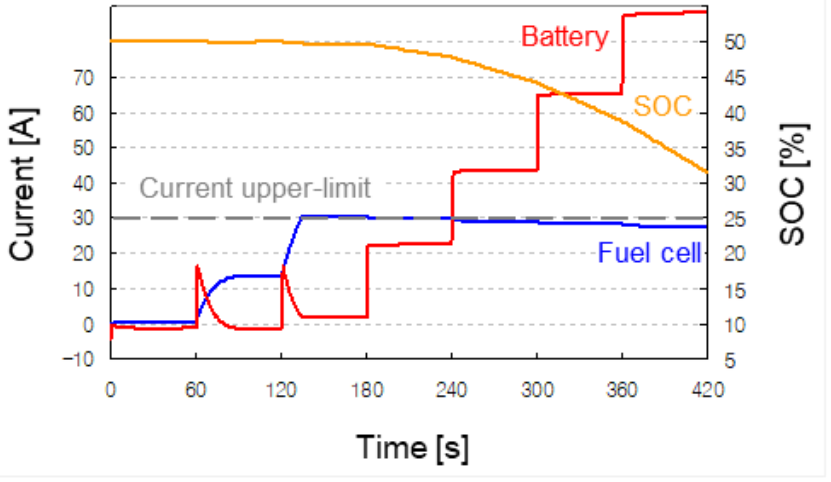

Figure 10. Simulated (a) power, (b) voltage, and (c) current with SOC of HPS under the overload condition.

Initially, with no load applied, the fuel cell power is approximately $+32 \mathrm{~W}$ (outgoing) and the battery power is approximately $-32 \mathrm{~W}$ (incoming), indicating that the power flows from the fuel cell to the battery. This power flow is induced by the voltage difference between the converter and battery. The reference voltage at the output of the converter was set as $25.15 \mathrm{~V}$ and the battery open-circuit voltage (OCV) was determined to be $25.129 \mathrm{~V}$ at an initial SOC of $50 \%$. With a slight voltage difference of less than $30 \mathrm{mV}$, a current of $1.3 \mathrm{~A}$ corresponding to a power of $32 \mathrm{~W}$ charges the battery.

At $60 \mathrm{~s}$, the load increases to $500 \mathrm{~W}$. Based on the differences in dynamic characteristics between the two power sources, the battery supplies power to the load before the fuel cell. After approximately $6 \mathrm{~s}$, their powers cross each other, and both bear the load equally at a power level of $250 \mathrm{~W}$. Then, approximately $15 \mathrm{~s}$ later, the fuel cell power reaches $500 \mathrm{~W}$, meaning the fuel cell can handle the load alone. Immediately thereafter, the fuel cell power 
slightly exceeds $500 \mathrm{~W}$, indicating that with this power surplus, the battery is charged. By doing so, the battery can maintain its initial SOC. At all times, the sum of all power flows should be equal to zero. By looking more closely at $60 \mathrm{~s}$, in response to the abrupt load change, the DC bus voltage instantaneously drops to $24.993 \mathrm{~V}$. Since the battery OCV remains at $25.114 \mathrm{~V}$, the voltage difference between them is reversed. In turn, a current close to $13 \mathrm{~A}$ begins flowing from the battery to the load.

At $120 \mathrm{~s}$, the load increases to $1 \mathrm{~kW}$. Again, the battery responds to the load earlier than the fuel cell. However, the fuel cell power is stabilized at approximately $955 \mathrm{~W}$ without overshooting and the power shortage $(45 \mathrm{~W})$ is covered by the battery. This is because the operating point of the fuel cell is fixed by limiting the reference current at the input of the converter to $30 \mathrm{~A}$. This threshold was set based on the user manual for the selected fuel cell [27], which warns that an over-current (OC) fault will occur if the current exceeds $30 \mathrm{~A}$. Therefore, the operating points at which the maximum output power is extractable are 31.136 V at 30.678 A from the fuel cell (high-side) and 25.095 V at 37.699 A from the load (low-side).

At $180 \mathrm{~s}$, the load steps up again to $1.5 \mathrm{~kW}$, which overloads the HPS. Under overload conditions, the battery is responsible for excessive power demands as high as $545 \mathrm{~W}$. As the battery continues to discharge at nearly $22 \mathrm{~A}, 60 \mathrm{~s}$ later, its OCV drops to $25.027 \mathrm{~V}$. The DC bus voltage accordingly drops to $24.821 \mathrm{~V}$ by deviating from its set point $(25.15 \mathrm{~V})$. The DC bus voltage remains greater than the rated voltage of the load $(24 \mathrm{~V})$ for $60 \mathrm{~s}$, but it could not be sustained.

When the load increases to $2 \mathrm{~kW}$ at $240 \mathrm{~s}$, the battery covers half of the power demand, so its voltage drop further accelerates. When the load is maximized at $3 \mathrm{~kW}$, it was predicted that the DC bus voltage eventually falls below the rated voltage of the load, thereby failing to meet the voltage requirements.

\subsection{Terminal Short-Circuiting}

The selected fuel cell is equipped with a short-circuiting method called a short-circuit unit (SCU). As its name implies, the SCU will short-circuit the fuel cell for 100 ms every $10 \mathrm{~s}$. According to the user manual [27], it is highly recommended to use the SCU at all times, which helps condition the fuel cell to enhance its durability. Although the SCU may be beneficial for the fuel cell, it could harm to the entire system by causing the fuel cell voltage to plummet repeatedly. The next simulation we performed focused on oscillating fuel cell voltages caused by the SCU and the resulting system instability.

In this simulation, the load was constant at $500 \mathrm{~W}$ (see Figure 11). At $10 \mathrm{~s}$, the SCU is set off, so the fuel cell is disconnected from the load for $100 \mathrm{~ms}$. The fuel cell power naturally drops to zero and the battery power compensates for that without delay. Therefore, when turning on the SCU, the HPS appears to be unaffected. Despite short-circuiting, the HPS can meet the voltage requirements across the DC bus. Rather, when turning it off, a fuel cell power surge is predicted. Considering the slow transient responses of fuel cells, the simulated recovery is too fast. Therefore, terminal short-circuiting will be examined again through actual tests.

\subsection{Drive Cycle}

The HPS of a security robot is similar to the powertrain in modern hybrid electric vehicles. For such vehicles, there is a drive cycle that is commonly used in the industry, and based on it, their powertrain can be designed and validated. However, this is not the case with our security robot, which is in the early specification development phase.

Despite limited knowledge regarding the actual operating conditions of the security robot, its operation mode was defined by modifying one of the popular drive cycles, namely a charge-depleting cycle life testing profile for an electric vehicle battery [28]. The modified drive cycle lasts for a total of $12 \mathrm{~min}$, with the security robot simultaneously surveilling and patrolling for the first half, and only surveilling for the second half (see Figure 12). Throughout this simulation, the electrical load required for surveillance was continuously 
applied and was uniform at $250 \mathrm{~W}$. The mechanical load required for patrolling was often added to that and varied above $200 \mathrm{~W}$. Overall, this simulation consists of three relatively light loads in a row followed by one heavy load (see Figure 12). The final simulation we conducted focused on the power flow in the load transitions from light to heavy and vice versa. The hydrogen flow rate was also used to double check the operating time estimated based on the energy.

(a)

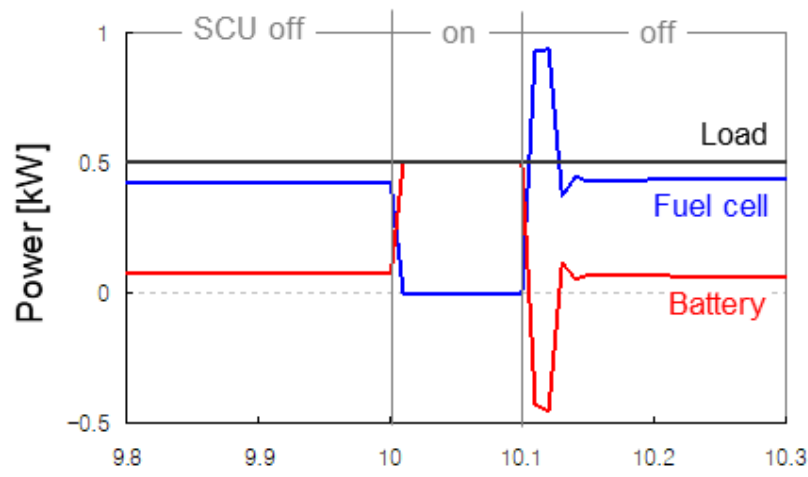

(b)

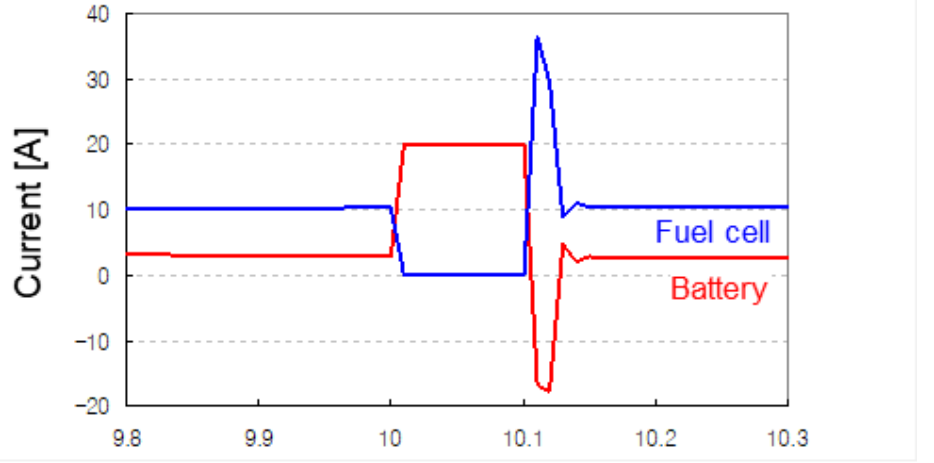

(c)

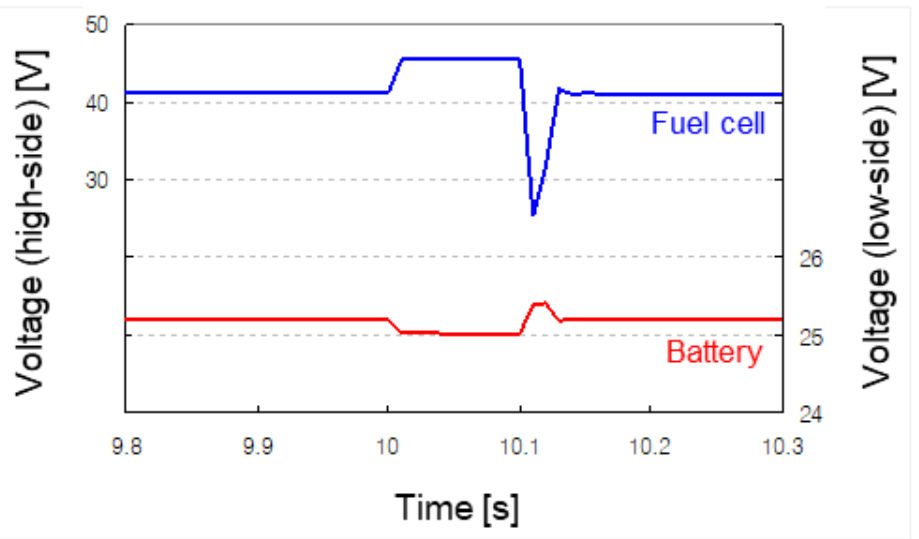

Figure 11. Simulated (a) power, (b) current, and (c) voltage of HPS under the short-circuit condition. 


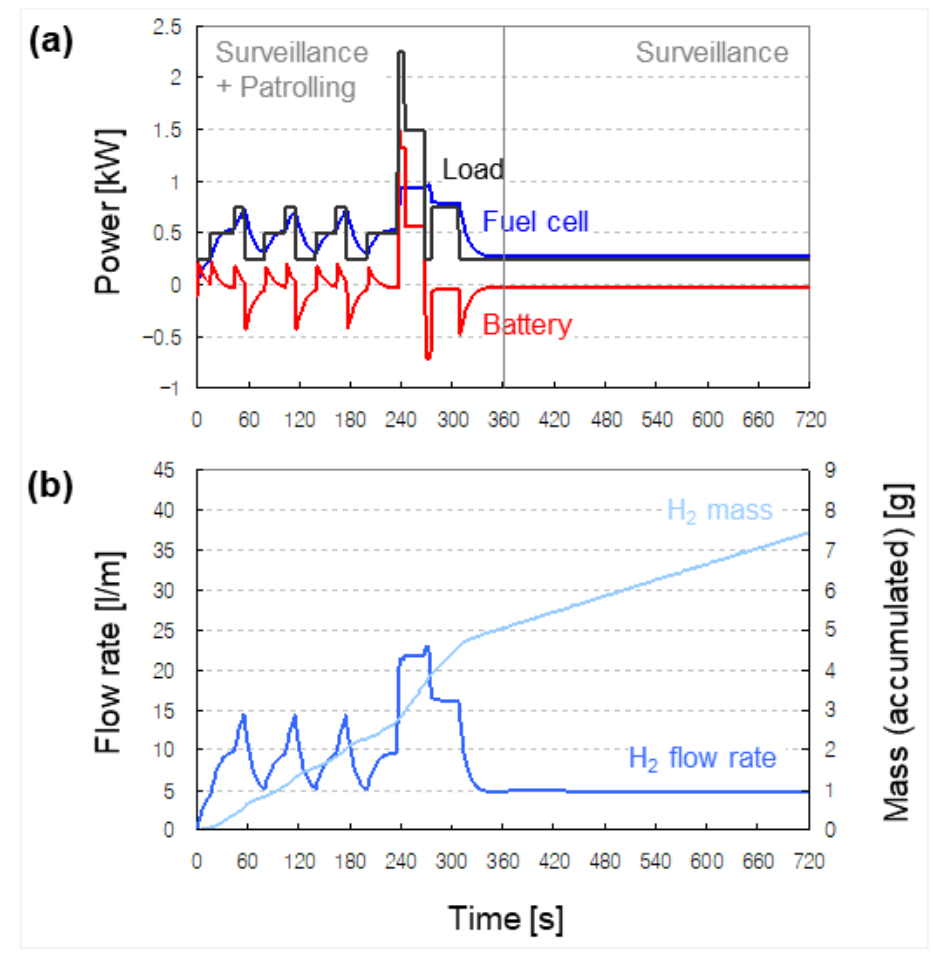

Figure 12. Simulated (a) power and (b) hydrogen flow rate with accumulated mass of HPS throughout a full cycle (until $720 \mathrm{~s}$ ).

Initially, the load increases to $250 \mathrm{~W}$, and $16 \mathrm{~s}$ later, it steps up to $500 \mathrm{~W}$ (see Figure 13). After $28 \mathrm{~s}$, the load steps up again to $750 \mathrm{~W}$. The maximum load is held for $11 \mathrm{~s}$, after which it steps down to $250 \mathrm{~W}$. Similar to the first simulation, compared to the battery, the slower transient response of the fuel cell can be clearly observed. Under rising loads, the battery provides power to the load before the fuel cell, ensuring the responsiveness of the entire system. Under a falling load, the fuel cell provides the power remaining after supply to the load with the battery, which promptly recovers its SOC. Therefore, the behavior of the entire system and its components is consistent throughout the three consecutive light loads.

Next, at $236 \mathrm{~s}$, the load suddenly increases to $2.25 \mathrm{~kW}$. After $8 \mathrm{~s}$, it steps back down to $1.5 \mathrm{~kW}$. In response to the heavy load, the fuel cell supplies power up to a maximum of $945 \mathrm{~W}$, which corresponds to a current less than or equal to $30 \mathrm{~A}$. As stated previously, this reflects the OC fault that protects the selected fuel cell. The battery power compensates for any shortcomings. At $360 \mathrm{~s}$, the first half of the drive cycle ends, and the second half continues until $720 \mathrm{~s}$.

We observed that the hydrogen flow rate increases with an increasing load (see Figure 12). The amount of hydrogen consumed per cycle is estimated to be approximately $90 \mathrm{~L}$, which is equivalent to $7.2 \mathrm{~g}$ based on the weight of $1 \mathrm{~L}$ of hydrogen $(0.08 \mathrm{~g})$. As mentioned previously, if compressed at 310 bar, the selected cylinders can store up to $0.71 \mathrm{~kg}$ of hydrogen, allowing them to complete 95 cycles on a single charge. Considering that the duration of each cycle is $12 \mathrm{~min}$, it was predicted that $19 \mathrm{~h}$ of continuous operation can be achieved. Based on our calculations, in electrical terms, the operating time was estimated previously. Through computer simulations, the results were cross-checked by evaluating hydrogen consumption to verify the consistency of the information provided. The result of falling short of the goal time of $24 \mathrm{~h}$ is understandable given that the load applied during the drive cycle, particularly the mechanical power required for patrolling, is greater than the average power. 


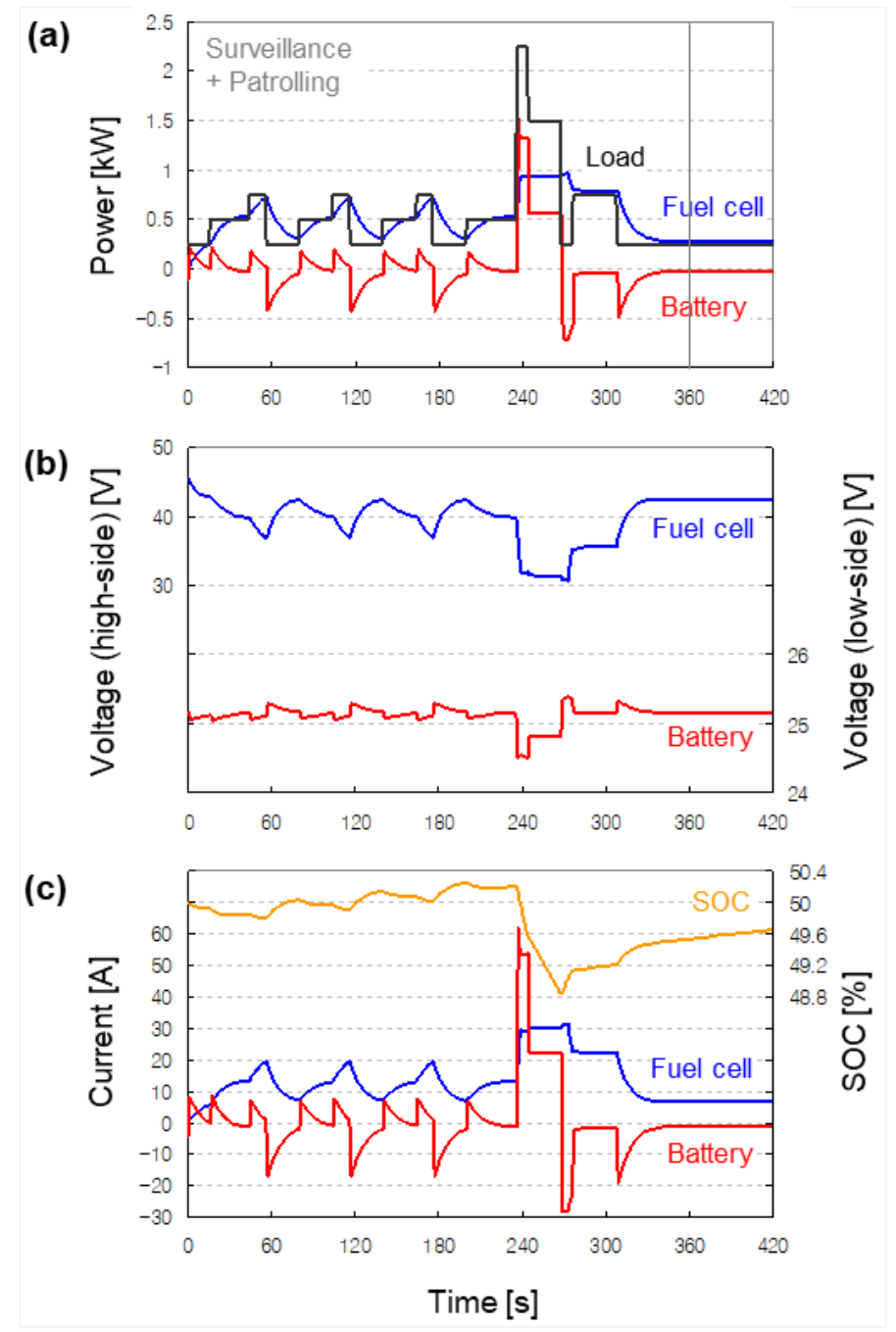

Figure 13. Simulated (a) power, (b) voltage, and (c) current with SOC of HPS throughout a half cycle (until $360 \mathrm{~s}$ ).

\section{Conclusions}

This paper presented the process of developing HPS specifications in a step-by-step manner. Among the HPS structures proposed thus far, the least costly configuration, namely the one-stage series structure, was selected with consideration for future mass production. The specifications of the components in the selected structure were determined based on the main development goals of our security robot, namely the climbable angle, operating time, and distance. Considering both performance and constructive metrics, the selected components were as follows: fuel cells with $1 \mathrm{~kW}$ nominal power, batteries with $20 \mathrm{Ah}$ nominal capacity, a DC/DC converter with $960 \mathrm{~W}$ rated power, and composite cylinders storing up to $0.71 \mathrm{~kg}$ of hydrogen compressed at 310 bar. Considering the operation modes of the security robot, the power required for patrolling $(200 \mathrm{~W})$ and surveillance $(250 \mathrm{~W})$ was estimated. By increasing the size of the fuel cell and battery to exceed the required power, the operational reliability of the HPS could be improved, particularly under overload conditions. Critical conditions accompanied by sudden load changes were simulated to verify the determined specifications. The simulations revealed that the HPS is able to cope well with critical conditions and can meet the voltage requirements across the DC bus. A few exceptions include terminal short-circuiting, where the fuel cell power surges when turning the SCU off. Under the modified drive cycle, the estimated operating time is approximately $5 \mathrm{~h}$ short of the goal time of $24 \mathrm{~h}$. To resolve these issues, actual 
tests are required with a HPS prototype and test bench. The HPS specifications developed through the process described in this paper will be passed into the next prototyping phase.

Funding: This work was supported by the Korean Evaluation Institute of Industrial Technology and conducted by the Ministry of Industry and Commerce in 2017 (Industrial Core Technology Development Project, Project Number 10080489).

Institutional Review Board Statement: Not applicable.

Informed Consent Statement: Not applicable.

Data Availability Statement: Not applicable.

Conflicts of Interest: The author declares no conflict of interest.

\section{References}

1. Advanced Observation \& Reporting. Available online: https://www.cobaltrobotics.com/ (accessed on 15 October 2021).

2. Robots: Augmenting Physical Security. Available online: https://www.cobaltrobotics.com/wp-content/uploads/2020/06/ Cobalt-Robotics-Whitepaper-Robots-Augmenting-Physical-Security.pdf (accessed on 4 September 2021).

3. Cobalt Robotics Introduces a (mostly) Autonomous Mobile Security Robot. Available online: https://spectrum.ieee.org/cobaltrobotics-introduces-mobile-security-robot (accessed on 1 November 2021).

4. O-R2, Multipurpose Concierge and Security Robot. Available online: https:/ / otsaw.com/o-r2-concierge-robot/ (accessed on 28 August 2021).

5. The K5 ASR-A Fully Autonomous Outdoor Security Robot. Available online: https://www.knightscope.com/k5/ (accessed on 11 September 2021).

6. Knightscope. Available online: https://www.knightscope.com/Knightscope-Corporate-Media-Kit.pdf (accessed on 17 September 2021).

7. Global Outlook for Mobile Security Robots. Available online: https://www.roboticsbusinessreview.com/wp-content/uploads / 2018/03/RBR-UGVs-For-Security.pdf (accessed on 3 October 2021).

8. Autonomous Security \& Disinfection Robot "PATORO". Available online: https://www.zmp.co.jp/en/products/lrb/patoro (accessed on 4 October 2021).

9. ROAMEO ${ }^{\mathrm{TM}} 2.0$ Is Ready for Patrol. Available online: https://roboticassistancedevices.com/roameo/ (accessed on 17 September 2021).

10. S5.2, Security Patrol Robot. Available online: https://smprobotics.com/products_autonomous_ugv/security-patrol-robot/ (accessed on 26 September 2021).

11. SMP Security Robot S5.2. Available online: https://smprobotics.com/wp-content/uploads/2019/04/security_robot_s52_smp_ robotics_2019.pdf (accessed on 1 August 2021).

12. The K7 ASR-A Multi-Terrain Autonomous Security Robot. Available online: https://www.knightscope.com/k7/ (accessed on 27 November 2021).

13. Ramos, G.A.; Montobbio de Pérez-Cabrero, T.; Domènech-Mestres, C.; Costa-Castelló, R. Industrial robots fuel cell based hybrid power-trains: A comparison between different configurations. Electronics 2021, 10, 1431. [CrossRef]

14. Di Trolio, P.; Di Giorgio, P.; Genovese, M.; Frasci, E.; Minutillo, M. A hybrid power-unit based on a passive fuel cell/battery system for lightweight vehicles. Appl. Energy 2020, 279, 115734. [CrossRef]

15. González, E.L.; Cuesta, J.S.; Fernandez, F.J.V.; Llerena, F.I.; Carlini, M.A.R.; Bordons, C.; Hernandez, E.; Elfes, A. Experimental evaluation of a passive fuel cell/battery hybrid power system for an unmanned ground vehicle. Int. J. Hydrogen Energy 2019, 44, 12772-12782. [CrossRef]

16. Ng, W.; Patil, M.; Datta, A. Hydrogen fuel cell and battery hybrid architecture for range extension of electric VTOL (eVTOL) aircraft. J. Am. Helicopter Soc. 2021, 66, 012009. [CrossRef]

17. Motapon, S.N.; Dessaint, L.A.; Al-Haddad, K. A comparative study of energy management schemes for a fuel-cell hybrid emergency power system of more-electric aircraft. IEEE Trans. Ind. Electron. 2014, 61, 1320-1334. [CrossRef]

18. Joo, D.M.; Woo, D.G.; Kim, D.W.; Lee, B.K. Control algorithm for portable fuel cell-battery hybrid system. In Proceedings of the 2012 IEEE Vehicle Power and Propulsion Conference, Seoul, Korea, 9-12 October 2012.

19. Larminie, J.; Lowry, J. Electric Vehicle Technology Explained, 2nd ed.; John Wiley \& Sons: Chichester, UK, 2012; pp. 159, 185, 220.

20. Pauwelussen, J.P. Essentials of Vehicle Dynamics; Butterworth-Heinemann: Oxford, UK, 2015; pp. 17-18.

21. Larminie, J.; Dicks, A.; McDonald, M.S. Fuel Cell Systems Explained, 2nd ed.; John Wiley \& Sons: Chichester, UK, $2001 ;$ p. 142.

22. Fuel Cell Stack-Implement Generic Hydrogen Fuel Cell Stack Model. Available online: https://kr.mathworks.com/help/ physmod/sps/powersys/ref/fuelcellstack.html (accessed on 19 August 2021).

23. Tremblay, O.; Dessaint, L.A. A generic fuel cell model for the simulation of fuel cell vehicles. In Proceedings of the 2009 IEEE Vehicle Power and Propulsion Conference, Dearborn, MI, USA, 7-11 September 2009.

24. Battery-Generic Battery Model. Available online: https://kr.mathworks.com/help/physmod/sps/powersys/ref/battery.html (accessed on 6 September 2021).

25. Tremblay, O.; Dessaint, L.A.; Dekkiche, A.I. A generic battery model for the dynamic simulation of hybrid electric vehicles. In Proceedings of the 2007 IEEE Vehicle Power and Propulsion Conference, Arlington, TX, USA, 9-12 September 2007. 
26. Buck Converter-Implement Buck Power Converter. Available online: https://kr.mathworks.com/help/physmod/sps/ powersys/ref/buckconverter.html (accessed on 19 September 2021).

27. H-1000 Fuel Cell Stack User Manual. Available online: https://www.fuelcellstore.com/manuals/horizon-pem-fuel-cell-h-1000 -manual.pdf (accessed on 20 October 2021).

28. Battery Test Manual for Plug-In Hybrid Electric Vehicles. Available online: https:/ /www.osti.gov/biblio/1010675-HTVXDL/ (accessed on 29 October 2021). 